\title{
Erratum to: Organizational Semiotics
}

\author{
Kecheng Liu ${ }^{1}$, Rodney J. Clarke², Peter Bøgh Andersen ${ }^{3}$, \\ Ronald K. Stamper ${ }^{4}$, and El-Sayed Abou-Zeid ${ }^{5}$ \\ 1 The University of Reading, United Kingdom \\ 2 University of Wollongong, Australia \\ 3 University of Aalborg, Denmark \\ 4 University of Twente/Staffordshire University, \\ The Netherlands/United Kingdom \\ ${ }^{5}$ Concordia University, Canada
}

\section{Erratum to: \\ K. Liu et al. (Eds.) \\ Organizational Semiotics \\ DOI: $10.1007 / 978-0-387-35611-2$}

The book was inadvertently published with an incorrect name of the copyright holder. The name of the copyright holder for this book is: (c) IFIP International Federation for Information Processing. The book has been updated with the changes.

The updated original online version for this book can be found at DOI: $10.1007 / 978-0-387-35611-2$ 